\title{
Essential Hypertension
}

National Cancer Institute

\section{Source}

National Cancer Institute. Essential Hypertension. NCI Thesaurus. Code C3478.

Hypertension that presents without an identifiable cause. 